\title{
A Framework for the Impact of IT on Organizational Performance
}

By: Tim Jacks, Prashant Palvia, Richard Schilhavy and Lei Wang

Jacks, T., Palvia, P., Schilhavy, R., and Wang, L. "A Framework for the Impact of IT on Organizational Performance". Business Process Management Journal. Vol. 17 No. 5, 2011, pp. 846-870. DOI 10.1108/14637151111166213

Made available courtesy of Emerald:

http://www.emeraldinsight.com/journals.htm?articleid=1951062\&show=html

*** Reprinted with permission. No further reproduction is authorized without written permission from Emerald. This version of the document is not the version of record. Figures and/or pictures may be missing from this format of the document. ***

\begin{abstract}
:
Purpose - Despite the constant stream of research investigating information technology (IT) business value, IT capabilities, and competitive advantage, researchers are calling for a more coherent understanding of the firm-level impacts of IT, and how those firm-level impacts can be measured. The purpose of this study is to investigate the multitude of organization-level studies of the impact of IT.

Design/methodology/approach - Meta-analysis of IS literature from 2001-2009.

Findings - The findings are synthesized into an overarching framework of the impact of IT at the organization level. The framework categorizes measures of the impact of IT into productivity, profitability, and intangible benefits, while the antecedents of IT impact are categorized into IT resources, IT capabilities, IT/business alignment and external factors.

Originality/value - The research framework proposed provides a comprehensive snapshot of IS studies on organizational performance.

Keywords: IT business value | organizational impact | productivity rate | profitability | financial performance | meta-analysis | information technology

Article:

1 Introduction
\end{abstract}

During the 1990s, many questioned the ability of information technology (IT) to substantially contribute to the firm's bottom line, a phenomenon referred to as the "productivity paradox" (Brynjolfsson, 1993). However, subsequent studies revealed significant effects of IT investments on both productivity and profitability of the firm (Brynjolfsson and Hitt, 1996). Further studies 
have demonstrated the continual importance of IT to the creation of business value and competitive advantage (Melville et al., 2004). However, common issues regarding the nature of the dependent variable (IT impact) and how to measure it (productivity, profitability) remain prevalent. Melville et al. (2004, p. 285) note that "IT business value scholars are motivated by a desire to understand how and to what extent the application of IT within firms leads to improved organizational performance.” For example, Tallon and Kraemer (2007) lament the lack of robust, firm-level measures of IT's impact and propose the use of perceptual measures in the absence of objective measures. Despite the constant stream of research on IT business value, IT capabilities, and competitive advantage, researchers are calling for a more coherent understanding of the firm-level impacts of IT and their measurement.

The purpose of this study is to investigate the multitude of organization-level studies on the impact of IT. A meta-analysis approach was used (Rosenthal and Dimatteo, 2001), extending the work of Kohli and Devaraj (2003) on the firm-level impacts of IT. Their meta-analysis covered 66 articles from the period 1990 to 2000. King and He (2005) suggested future researchers extend this vein of research utilizing a similar meta-analysis design strategy as Kohli and Devaraj (2003). In order to build on the cumulative tradition, this study captures current IT impact research using a similar research design. The meta-analysis explores nine years (20012009) and 76 articles concerning the impact of IT at the firm or organizational level resulting in a comprehensive 20-year snapshot of IT impact research. The findings are synthesized into an overarching framework. Specifically, the study addresses the following research questions:

$R Q 1$. What are the dominant firm-level dependent variables in organizational-IT literature?

$R Q 2$. What are the dominant antecedents process- or firm-level independent variables) that affect firm-level performance?

The rest of the paper is organized as follows. Section 2 offers prior theoretical frameworks on IT impact on organizational performance. Section 3 details the methodology of the meta-analysis including the complete coding scheme. Section 4 provides results of the analysis. Section 5 proposes a new parsimonious framework for examining the literature in categories of independent and dependent variables. Section 6 offers some discussion of the meaning of the findings. Sections 7-9 provide the contributions, limitations and future research, and conclusions, respectively.

\section{Theoretical framework}

Many theoretical frameworks have sought to explain IT's impact on organizational performance. An early example is Porter and Millar's (1985) seminal work on the value chain, where information has the ability to provide value in each link of a firm's value chain. An especially pervasive theoretical framework is the resource-based view (RBV) of the firm, which holds that a resource must meet four criteria in order to create value: 
1. valuable;

2. rare;

3. hard to copy; and

4. non-substitutable (Wernerfelt, 1984; Barney, 1991).

Organizations are amalgams of physical, human and knowledge resources that confer competitive advantage to the firm that can control and leverage the unique characteristics of the resource (Melville et al., 2004). In contrast, Carr (2003) critically questions the value IT is able to confer to the firm, precisely because IT resources have become commoditized and are therefore no longer rare or hard to imitate. Certainly, some IT assets are not difficult to duplicate, such as infrastructure and networking components; however, resources alone do not explain the difference of firm's competitiveness. Teece's (1997) dynamic capabilities theory effectively addresses this issue. The dynamic capabilities theory extends the RBV, but emphasizes capabilities instead of merely assets as the source of competitive advantage:

Winners in the global marketplace have been firms that can demonstrate timely responsiveness and rapid and flexible product innovation, coupled with the management capability to effectively coordinate and redeploy internal and external competences (Teece et al., 1997, p. 515).

In other words, firms cannot rely on procuring IT infrastructure as a necessary condition for sustained competitive advantage, but must also possess and nurture internal capabilities to manage that infrastructure effectively.

The RBV remains the dominant theoretical explanation of IT business value as evidenced by Melville et al.'s (2004) comprehensive literature review. They found two main formulations of performance:

1. efficiency; and

2. effectiveness.

Their overall framework was supported by the RBV with IT and complementary organizational resources supporting business processes that lead to organizational performance (Melville et al., 2004). Similarly, Piccoli and Ive's (2005) literature review of how IT-dependent strategic initiatives lead to sustained competitive advantage uses the RBV with elements of dynamic capabilities theory. The framework identifies four barriers to the erosion of sustained competitive advantage:

1. IT resources;

2. complementary resources; 


\section{IT projects; and}

4. pre-emption coupled with two dynamic capabilities which reinforce these four barriers:

o organizational learning; and

o asset stock accumulation (Piccoli and Ives, 2005).

Kohli and Devaraj's (2003) meta-analysis of IS literature on structural variables of IT payoff studies between 1990 and 2000 found empirical support for a number of propositions. IT payoff studies differ depending on the industry sector, sample size, data source, and type of dependent variable (Kohli and Devaraj, 2003). In addition, the authors provide a useful conception of IT impact for our meta-analysis by categorizing dependent variables as either "profitability” and "productivity".

A different but related stream of research on IT value focuses on the Delone and McLean (1992) theoretical framework of IS success. IS success is comprised of many dimensions, including system quality, information quality, use, and user satisfaction which lead to individual impact and ultimately organizational impact (Delone and McLean, 1992). This framework was later extended to include service quality as a fifth form of IS success and organizational impact was broadened to include "net benefits" as an outcome (Delone and McLean, 2003). However, a more recent review of IS success model literature indicated that the dimension of service quality received no attention in 34 journals from 2003 to 2007 (Urbach et al., 2008). The dominant paradigm of recent IS success research focuses on user evaluations via surveys regarding the impact of a particular information system resulting in a structural equation model (Urbach et al., 2009).

There does not seem to be any more skepticism since Carr (2003) that IT does, in fact, provide firm-level value or since Brynjolfsson (2000) that there is any more productivity paradox (Kohli and Devaraj, 2003). However, the empirical studies in IS literature on what that value is and how it is to be measured remains fragmented. There is no consistent set of performance measures. Conducting a meta-analysis of the literature is a useful means of critically examining disparate findings (Wolf, 1986) and furthermore, meta-analysis of IS literature is necessary to bolster the cumulative tradition of the discipline (Hwang, 1996).

3 Methodology 
The methodology for this meta-analysis required a systematic selection of articles that fit the research questions. The term "meta-analysis" was first coined in psychology by Glass (1976) as simply an "analysis of analyses." Rosenthal and Dimatteo (2001, p. 61) elaborate that "the quantitative procedures of meta-analysis help to address some of the challenges introduced by the existence of multiple answers to a given research question." Meta-analysis has become an accepted way of synthesizing a large body of work into something more manageable. A broader view of research that describes the emerging theoretical landscape may be of greater value than the individual results (Rosenthal and Dimatteo, 2001), allowing researchers to see the forest through the trees.

The target pool of articles included seven top-tier journals covering a nine-year period from 2001 to 2009. The journals were:

1. MIS Quarterly;

\section{Information Systems Research;}

3. Journal of MIS;

4. Decision Sciences;

5. Management Science;

6. Information \& Management; and

7. Journal of Global Information Technology Management (JGITM).

The first six journals are among the top journals in information systems research as reported by various rankings on the web site of the Association for Information Systems. One of the issues of interest was the depth of key global IT issues in the IT value literature. While measuring the business value of IT is a key management concern in advanced countries, it has been less emphasized in newly industrialized countries, developing countries, and underdeveloped countries (Palvia and Pinjani, 2007). Therefore, JGITM was selected as a premier journal for global IS studies as the seventh journal examined. The authors performed several rounds of comparing candidate articles until consensus was achieved regarding whether the selection criteria was consistently interpreted and applied. The initial search resulted in 95 articles. Of these, 16 were ultimately excluded since the selected article did not meet the selection criteria. The resulting 76 articles (Appendix 1) provided the basis for this meta-analysis. The selection criteria covered three main points:

1. The article's level of analysis had to be at the organization or firm level or higher, such as industry, nation, or society. Articles that studied at the departmental level, project team level, or individual level were excluded due to the focus of the study. 
2. Organizational performance or success had to be one of the main constructs. While there are many ways that IS can indirectly affect firm performance, studies were limited to ones that addressed firm-level performance (or higher) directly. In other words, an article that finds IS knowledge management leads to higher productivity of individuals was excluded.

3. The articles had to include empirical evidence. Theoretical or review articles were therefore excluded

These three selection criteria mirror that of Kohli and Devaraj (2003) and therefore form a basis for comparison between the two studies. Because of this similarity, we extended our timeframe back to 2001 in order to pick up where Kohli and Devaraj (2003) left off in 2000. Articles were identified by both keyword search in library databases (first step) and manually reading all abstracts in each issue of the targeted journals (second step). The second step contributes to the reliability of the article selection process as many meta-analyses rely solely on the first step of keyword searching. The specific keywords used were operationalized using some of the keyword classification developed by Barki et al. (1993). The number of useful and appropriate keywords developed into a considerably lengthy list, therefore, keywords were divided into primary and secondary keywords. The primary keywords formed the database search.

The complete list of keywords in Table I is contributes to future research in the field. The primary keywords were considered the most targeted, however, the secondary keywords were important considerations in the early stages of research. By way of comparison, Kohli and Devaraj (2003) used the brief keyword list of IT payoff, IT, firm, productivity, firm performance, technology, and profitability. Our list of possible keywords was established after several rounds of deliberation amongst the research team, based on domain knowledge and experience. The additional step of reading all the abstracts of all the targeted journals instead of relying on keyword journals helped to eliminate errors of exclusion whereas the group discussions about the articles that were selected helped eliminate errors of inclusion.

The first round of article selection demonstrated a low-inter-rater reliability among the researchers (below 0.50, where coefficients greater than 0.90 are necessary). The low-inter-rater reliability can be accounted for by:

- poor initial formulation of the problem, particularly level of analysis;

- inclusion of non-empirical research on the impact of IT management practices, and not IT itself; and

- ambiguity of terms, particularly variable and construct names. 
Two additional selection rounds were conducted not only to improve the inter-rater reliability, but also to address issues in research design and selection. After several iterative rounds of selection, as is typical in meta-analysis research (Wolf, 1986), the selection criteria and definitions reached a shared understanding by the three coders with an inter-rater reliability of 100 percent. Wolf (1986) identifies best practices for enhancing inter-rater reliability in a meta-

analysis and these were followed. The coding form was pilot-tested, an explicit codebook keyed to the form was developed, coder training was performed, the codebook was revised and coders retrained as needed, no new coders were added, and coders were actively involved in discussions and decisions about coding rules.

\section{Coding process}

A coding scheme was used for the structure of the database for recording and coding all articles. Fields were created in the database for the following: keywords, research questions, key findings, methodology and model based on the lists provided in Palvia et al. (2006), variables and their type, hypotheses and whether they were supported or unsupported, topic areas, whether the data were primary or secondary, sample size and level of analysis, whether the data were crosssectional or longitudinal, and any global issues. The structural variables of data source (primary or secondary), data type (longitudinal or cross-sectional), sample size, and dependent variable type were used in Kohli and Devaraj's (2003) meta-analysis and thus added to ours in order to provide continuity. The complete coding scheme is included in Table II.

\section{Analysis and results}

Aggregate findings

The analysis resulted in a number of interesting findings. Table III shows the results of the distribution of journal articles in descending order. The table indicates that the Journal of MIS and Information \& Management had the two highest counts in the area of IT impacts on organizational performance. Note that Kohli and Devaraj's (2003), meta-analysis reported Management Science and Information Systems Research as their highest two. The fact that their selection process was based on keyword searches alone may account for some of this difference, as well as a shift in which journals were pursuing this topic in the 2000s compared to the 1990s. 
Figure 1 shows the frequencies of journal articles on organizational impact for the nine-year, 2001-2009 period. The 11-year period from 1990 to 2000 is also shown in black reflecting the results from Kohli and Devaraj's (2003) meta-analysis. Figure 1 shows a full 20-year snapshot of the literature in this area. The result shows that the trend increased dramatically through 2007 and quickly diminished. This may be an indicator of the life cycle of this research topic. We note that the initial rise in popularity of the topic around 2004 corresponds with Melville et al.'s (2004) MISQ review of the topic.

Tables IV and V show the top models and methodologies in descending order. The list of possible models and methodologies came from Palvia et al. (2006). The totals are greater than the number of articles because several articles were coded with two models and/or methodologies. The top methodology type was survey followed by mathematical analysis. The top model type was multi-tier influence diagram. These findings are consistent with the more general rankings found in Palvia et al. (2006) as well as the findings in Urbach et al. (2009). Multi-tier influence models based on survey data are the dominant paradigm in IT impact studies.

Ten articles were coded as relating to global issues, or 13 percent of the articles. Table VI shows the list of global issues that were coded in the meta-analysis. However, if one uses a strict definition of "global" as being a study that involves more than a single country (Palvia, 1998) then only three articles were truly global (Park et al., 2007; Swierczek et al., 2005; Zhu et al., 2005 in Table VI).

Variables

The dependent variable of IT value for organizational performance was deliberately interpreted broadly for the initial article selection. The goal was to find all kinds of success, not just financial success. After reviewing the articles, the authors identified three broad categories of organizational performance or success. Based partially on Kohli and Devaraj (2003) categorizations of productivity and profitability, the dependent variable categorizations was extended to include intangible benefits as a third category. Profitability may be better termed "financial performance" as items such as market share and sales were coded as profitability. Technically, it is certainly possible to increase market share and sales while profitability decreases. Productivity is another broad term. Technically speaking, production as output is distinct from improving the internal process that generates that output. Productivity includes both 
output improvement and process improvement. The last category captured items that were neither profit related nor production related, and therefore was defined broadly as intangible benefits. Table VII shows a complete list of all the dependent variables that were used in the literature in the period of analysis. The breakdown of articles by category was 50 percent used profitability measures, 43 percent used productivity measures, and 7 percent used intangible benefits. About 8 percent of the articles used both profitability and productivity. About 4 percent used both profitability and intangible benefits.

\section{Proposed framework}

Some recurring themes emerged during the meta-analysis. The dependent variables fell naturally into three logical categories. IS makes an organization successful by either making the organization more profitable, more productive, or by an intangible benefit. Examples of profitability from the meta-analysis articles included items, such as sales growth, profits, return on investment, costs, and market share. Examples of productivity included items such as business process outcomes, labor productivity, operational efficiency, production output, and service performance. The intangible category included seven items: customer satisfaction (goodwill), industry performance (dynamism, longevity, visibility, reputation), human resource management, number of downloads, public image and client loyalty, quality improvement, and social productivity (in an economic sense). While this category is small, it seemed important to show that not all measures are related to profitability or productivity.

The independent variables required more deliberation and thought. Categorizing 177 independent variables from the meta-analysis was challenging. As it is important to have a parsimonious model and still capture the landscape of IS success, the categories must be broad. There are a growing number of studies in the area of IT impact on organizational performance but to date no one has tried to bring together this highly complex field of research into a single framework.

\section{First category: resources}

The first category came from the trend in many theoretical frameworks. The RBV holds that resources can bring competitive advantage to an organization if they are:

- valuable;

- $\quad$ rare; 
- hard to copy; and

- non-substitutable (Wernerfelt, 1984; Barney, 1991).

The RBV has been used frequently in IS literature to explain how IS creates competitive advantage (Melville et al., 2004; Piccoli and Ives, 2005). Since the resources of the firm are critical in conferring competitive advantage, the first category identified consisted of IS-related organizational resources in the firm. A wide variety of resources was captured in the metaanalysis and included items such as: IT infrastructure, IT applications, specialized knowledge of managers and users, and IT system characteristics. These were consistent with Bharadwaj's (2000) conceptualization of resources as being related to IT infrastructure, human IT performance, and IT-enabled intangibles such as knowledge. Most resources met the criteria of being valuable, rare, hard to copy and non-substitutable, even though not all of the articles were explicitly referencing the RBV. Of the 177 independent variables used in the meta-analysis, 95 met the definition of resources.

Second category: capabilities

The second category of independent variables is capabilities. Teece (2007, p. 1319) defines dynamic capabilities as capacities:

(1) to sense and shape opportunities and threats (2) to seize opportunities, and (3) to maintain competitiveness through enhancing, combining, protecting, and when necessary, reconfiguring the business enterprise's intangible and tangible assets.

IS capabilities, in particular, can contribute to rapid-paced competitive advantage for a firm (Wade and Hulland, 2004). Capabilities are a necessary, but not sufficient, source of sustained competitive advantage because they can potentially be copied (Wheeler, 2002). Examples of capabilities from the meta-analysis include items such as integration with supply chain partners, electronic collaboration, IS planning, and innovation. Of the 177 independent variables used in the meta-analysis, 45 met the definition of capabilities.

Third category: IT/business alignment

IT/Business alignment has been a top concern of C-level business executives for over 25 years. Alignment can be defined as the level of harmony, integration, or synchronization between IT and their business unit counterparts (Luftman and Kempaiah, 2007). This alignment or lack thereof can affect perceived IT business value (Tallon and Kraemer, 2007). Alignment is more than a simple capability and includes aspects of organizational culture as well as strategic planning. Enablers of IT/business alignment can include senior executive support for IT, IT understanding the business, partnership between IT and business, and IT plans being linked closely to overall business plans (Luftman and Kempaiah, 2008). Furthermore, alignment 
maturity is rising (Luftman and Kempaiah, 2007). Examples of IT/business alignment variables from the meta-analysis included items such as business planning, business strategy, CEO-IT distance, IT strategy, and top management support for IT. Of the 144 independent variables used in the meta-analysis, 28 met the definition of alignment. Many articles covered all three of the first three categories of resources, capabilities, and IT/business alignment, but all articles addressed at least one of them.

Fourth category: external factors

A few variables did not easily fit into the first three categories. These included items such as geographic scope, international scope, lowered cost of infrastructure, market characteristics, supply chain demand uncertainty, and supply chain demand volatility. After reflection, the commonality was found to be that they were all external to the organization. Resources, capabilities, and IT/business alignment are all internal concerns. It would follow then that the remaining variables would encompass external factors, outside the organization's direct control, that affect how IT influences organizational performance. Therefore, the fourth and final factor was identified as external factors. Of the 177 independent variables used in the meta-analysis, 9 met the definition of external factors.

The breakdown of variables according to these four categories of antecedents is shown in Table VIII and the complete list of independent variables is shown in Appendix 2. This framework of four categories of antecedents and three categories of consequents was not created a priori to the studies in the meta-analysis but rather entirely built from the data as revealed in the metaanalysis. The framework outlines a "recipe” of sorts for how IS can impact organizational performance in terms of what a firm has (resources), what it can do (capabilities), how it does it (IT/business alignment) and in what context (external factors).

Based on the above analysis, the following framework in Figure 2 is proposed to describe the recent landscape of literature on IS's impact on organizational performance. This framework may serve to assist future research in IS success to form new hypotheses.

6 Discussion 
In general, there was wide support for the impact that IS has on organizational performance and the idea that IS has an impact on organizational performance does not seem to be an issue as much as how. This meta-analysis answers the RQ1. by showing how IS impacts the organization in three main ways: profitability, productivity, and other intangible benefits. It answers the RQ2. by showing that the main factors by which IS impacts the organization are through resources, capabilities, IT/business alignment, and external factors.

Another interesting finding is the dependent variable used to measure firm-level impact of IT varied widely across multiple dimensions. First, dependent variables were broadly measured in terms of productivity and performance. Productivity measures of IT impact include corporate, organization or firm performance and productivity; plant and labor performance and productivity; online and systems technical performance; and business process and operation efficiency. Second, dependent variables were highly contextual on the phenomenon investigated, further underscoring the need for a cohesive framework on the elusive "IT dependent variable." Some dependent variables did not fit into the major categories of productivity or profitability, such as number of downloads, improved image, and perceived improvements, and were categorized by themselves as intangible benefits.

This study echoes the need for more research into the dependent variable of information systems and IT research. The sheer number of dependent variables used to study the impact of IT underscores the complex nature of IT impacts and the difficulty of measuring firm- and organization-level phenomena. As the field of IT evolves, the nature of IT impact changes and what was the gold standard of one decade may have to be replaced. Many researchers have laid claim to the dependent variable of information systems, such as the original Delone and McLean IS success model (Delone and McLean, 1992), but IS success is more complicated than first expected, as evident in the reformulation of the concept (Delone and McLean, 2003). Moreover, even though system quality was added in their reformulated model (Delone and McLean, 2003), Urbach et al. (2008) note that system quality has not received empirical attention in the literature. In their conclusion, Kohli and Devaraj (2003, p. 137) state that "structural variables do influence the outcomes of IT payoff studies” and recommend the following:

- $\quad$ future studies should gather data from primary sources whenever possible;

- $\quad$ researchers should gather larger sample sizes;

- $\quad$ researchers should gather longitudinal data; and

- $\quad$ productivity-based dependent variables are better suited to assess payoff results than those based on profitability. 
As points of comparison, our study finds IT impact studies predominately came from primary sources, with 54 articles using primary sources and 25 using secondary sources. This is in sharp contrast to Kohli and Devaraj's (2003) 24 studies using primary sources and 42 using secondary sources. It seems clear that there was a strong shift from secondary to primary sources moving from the 1990s to the 2000s.

The mean sample size was 299, which is reasonably large. Raw mean values were not provided in Kohli and Devaraj (2003) to allow for comparison. For data type, 75 percent of the studies were cross-sectional, not longitudinal, despite Kohli and Devaraj's call for more longitudinal studies. In fact, just the opposite happened. They reported 73 percent longitudinal studies and 23 percent cross-sectional studies - the ratio of longitudinal to cross-sectional studies inverted from the 1990s to the 2000s. The emphasis on cross-sectional studies reflects the field's continued heavy use of survey methods for data collection. This finding agrees with Urbach et al.'s (2008) analysis that quantitative-empirical analysis is the primary methodology for measuring IS success. This dramatic shift may also be due to the change from more secondary sources in the 1990s to more primary sources in the 2000s.

Finally, the distribution of productivity versus profitability dependent variables in Figure 2 shows that while profitability variables (50 percent) maintain a slim majority over productivitybased variables (43 percent). Kohli and Devaraj (2003) reported 60 percent profitability dependent variables and 40 percent productivity variables. Thus, the shift to more productivitybased dependent variables called for by Kohli and Devaraj (2003) did occur, although only slightly, in the 2000s.

A more surprising finding was that despite the constant drive of globalization and the subsequent importance of IS research in multi-national firms, the study found surprisingly few studies that explored the impact IT has on multi-national firms in a truly global context. There may be several explanations for this finding. First, as evidenced by the "productivity paradox" (Brynjolfsson, 1993) and the general difficulty of conducting firm-level studies, these issues are further exacerbated on an international scale in multi-national firms. Additionally, political, regulatory, and cultural variables as external forces may confound the organizational level findings. Second, due to the large sample size necessary to find significant effects of IT at the organizational level (Kohli and Devaraj, 2003), researchers may find it difficult to reach the target sample size in global comparative studies. Of final note, is what we did not see in IS research. As Table VII indicates, the vast majority of dependent variables (93 percent) examined in the literature are related to either profitability or productivity with only 7 percent looking at other kinds of organizational success. These findings can be juxtaposed with a recent article in 
CIO magazine, a popular trade journal, which identified four ways in which CIOs create core value for their organizations. These are:

1. financial (lowering business costs, increasing profits);

2. operational (increasing efficiency, creating improvements);

3. customers (choices of products and services); and

4. social impact (improvements to education, health, safety, or the environment) ( $\mathrm{CIO}$, 2009).

While the first two match up with our first two categories, the third category is reflected in only 7 percent of the meta-analysis articles (what we named "intangible benefits"), while the fourth category did not come up at all in the meta-analysis. In order to stay relevant to practitioners, we would encourage future IS research to look more closely at topics around customer service and social impact.

\section{Conclusions/contributions}

This study contributes to research in several ways. First, it expands the prior concept of only two types of dependent variable in IT value research (profitability and productivity) to include a third, namely intangible benefits. A multi-dimensional construct is necessary to fully capture the complex, multi-faceted impact IT has on organizations. Second, it extends the work of Kohli and Devaraj (2003) to provide a comprehensive 20-year view of the literature on IT value. Third, it provides a more rigorous method by reviewing all the abstracts from the targeted journals as opposed to relying on keyword searches alone as done in other meta-analyses. Fourth, it provides a new theory-based framework for categorizing the independent variables that serve as antecedent factors of organizational performance due to IT. The contribution to practice is an accessible overview of academic literature over a 20-year period that outlines what has been measured in the past and what might be measured in the future.

Although individual hypotheses and the support (or lack of support) was captured, this data has not been fully analyzed due to the relative complexity of the data (dependent and independent variables) to the number of articles and hypotheses coded. Some variables, such as firm performance or financial benefits, had several hypotheses associated with them. However, the multitude of independent and dependent variables without replication exacerbates further analysis. A second categorization of variables (for example, consistent with the proposed 
research framework) or an expansion of the selection domain including more journals and more years may alleviate this issue.

In terms of other limiting factors, while the sample size seems adequate compared to other metaanalysis studies, the data gleaned from the analysis are purely observational and not randomized in any way. While no statistical generalizability is being claimed, the generalizations of the literary landscape in this framework are fairly representative.

One interesting issue that arises through both the selection, coding and analysis process of the study was the sheer inconsistency of how firm-level studies of IT impact operationalized both independent and dependent constructs. On the one hand, this posed a severe roadblock and limitation to the coding and analysis process. However, the inconsistent operation of firm-level constructs and variables offers abundant opportunity to synthesize and operationalize robust firm-level constructs of the impacts of IT.

While global issues were coded and captured for each of the 76 articles in the meta-analysis, few studies had any resemblance of global or international issues. Even considering that the JGITM, a journal that focuses exclusively on the global application of IT, few firm- or organizationallevel studies were found. As mentioned before, this may be due to the difficulty of conducting firm-level studies in multi-national corporations. Certainly, the global context will be a rich area for future empirical studies and we would call on researchers to examine more global issues in their work. The definitions of success itself may be viewed differently in different national cultures. Another prime topic for future studies is in the area of IT in healthcare.

In summary, the authors conducted a meta-analysis of 76 articles over a nine-year period from 2001 to 2009 in the IS literature on the impact of IT on organizational performance. By extending the work of Kohli and Devaraj (2003), a comprehensive 20-year snapshot of the landscape of IT value research was provided. The findings included a framework of three major dependent variables (profitability, productivity, and intangible benefits) and four major independent variables (business alignment, resources, capabilities, and external factors). Measures of performance continue to be fragmented in the literature. Studies using primary data sources and cross-sectional data collection have increased in the 2000s compared to the 1990s and productivity studies have increased slightly over profitability studies. While there is an overall trend of increasing research in this area, IT value research should extend its life cycle by 
focusing on issues around global contexts, social issues, and healthcare in order to stay relevant to practitioners.

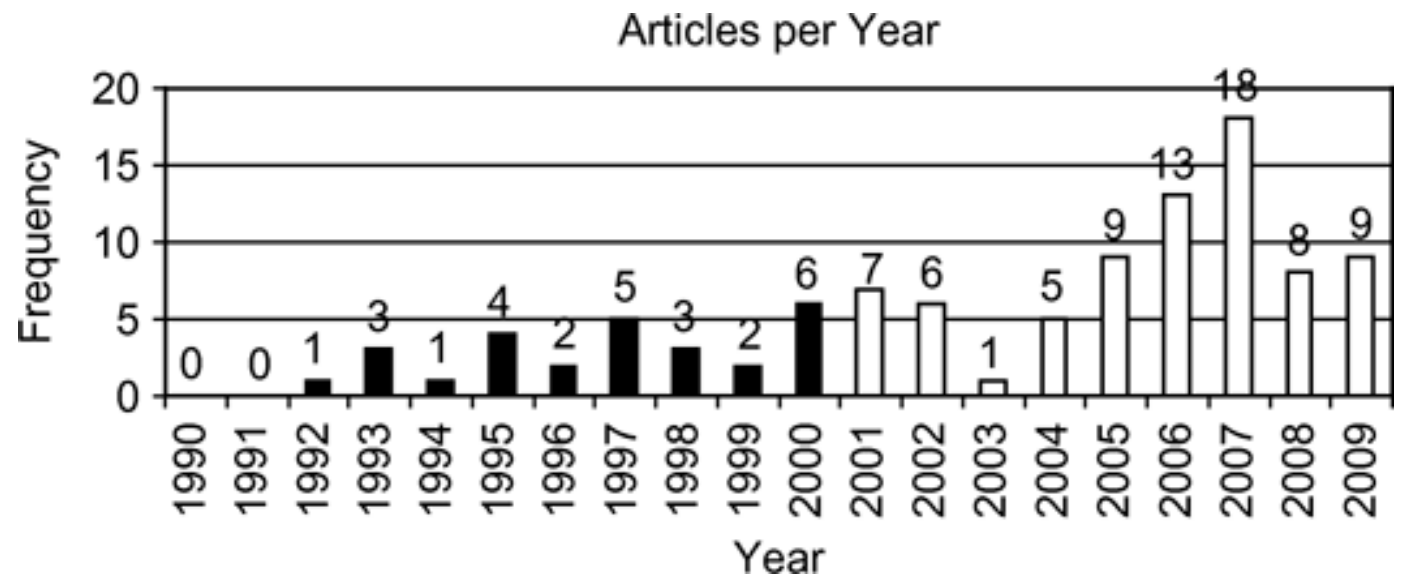

Figure 1Distribution of articles by year

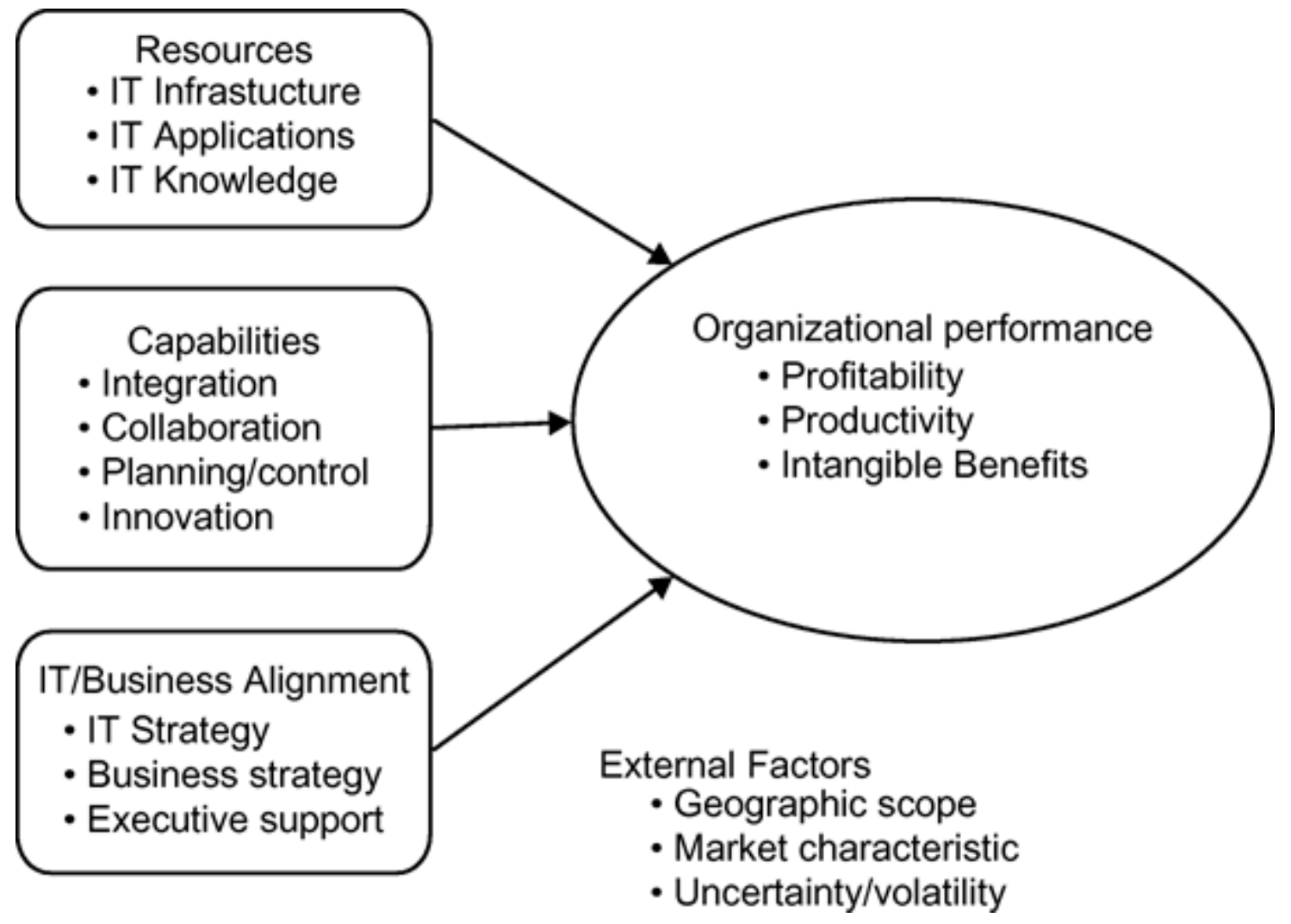

Figure 2Proposed framework

Tables 1-8 have been omitted from this formatted document. 


\section{References}

Barki, H., Rivard, S., Taibot, J. (1993), "A keyword classification scheme for IS research literature: an update", MIS Quarterly, Vol. 17 No.2, pp.209-26.

Barney, J. (1991), "Firm resources and sustained competitive advantage", Journal of Management, Vol. 17 No.1, pp.99-120.

Bharadwaj, A. (2000), "A resource-based perspective on information technology capability and firm performance: an empirical investigation", MIS Quarterly, Vol. 24 No.1, pp.169-96.

Brynjolfsson, E. (1993), "The productivity paradox of information technology", Communications of the ACM, Vol. 36 No.12, pp.66-77.

Brynjolfsson, E. (2000), "Beyond computation: information technology, organizational transformation and business performance",Journal of Economic Perspectives, Vol. 14 No.4, pp.23-48.

Brynjolfsson, E., Hitt, L. (1996), "Paradox lost? Firm-level evidence on the returns to information systems spending", Management Science, Vol. 42 No.4, pp.541-58.

Carr, N.G. (2003), "IT doesn't matter", Harvard Business Review, Vol. 81 No.5, pp.41-9.

CIO (2009), "How focusing on customers, collaboration and cost control delivers business value", CIO, 1 August, .

Delone, W.H., McLean, E.R. (1992), "Information systems success: the quest for the dependent variable", Information Systems Research, Vol. 3 No.1, pp.60-95.

Delone, W.H., McLean, E.R. (2003), "The DeLone and McLean model of information systems success: a ten-year update", Journal of Management Information Systems, Vol. 19 No.4, pp.9-30.

Glass, G.V. (1976), "Primary, secondary and meta-analysis of research", Educational Researcher, Vol. 5 No.9, pp.3-8.

Hwang, M.I. (1996), "The use of meta-analysis in MIS research: promises and problems", DATA BASE for Advances in Information Systems, Vol. 27 No.3, pp.35-48.

King, W.R., He, J. (2005), "Understanding the role and methods of meta-analysis in IS research", Communications of the Association for Information Systems, No.16, pp.665-86.

Kohli, R., Devaraj, S. (2003), "Measuring information technology payoff: a meta-analysis of structural variables in firm-level empirical research", Information Systems Research, Vol. 14 No.2, pp.127-45. 
Luftman, J., Kempaiah, R. (2007), "An update on business-IT alignment: 'a line’ has been drawn", MISQ Executive, Vol. 6 No.3, pp.165-77.

Luftman, J., Kempaiah, R. (2008), "Key issues for IT executives 2007", MISQ Executive, Vol. 7 No.2, pp.99-112.

Melville, N., Kraemer, K., Gurbaxani, V. (2004), "Information technology and organizational performance: an integrative model of IT business value", MIS Quarterly, Vol. 28 No.2, pp.283322.

Palvia, P. (1998), "Global information technology research: past, present, and future", Journal of Global Information Technology Management, Vol. 1 No.2, pp.3-14.

Palvia, P., Pinjani, P. (2007), "Challenges of the global information technology management environment: representative world issues", in Palvia, P., Palvia, S., Harris, A. (Eds),Managing Global Information Technology: Strategies and Challenges, Ivey League, Marietta, GA, .

Palvia, P., Midha, V., Pinjani, P. (2006), "Research models in information systems", Communications of the Association for Information Systems, Vol. 17 No.47, pp.104263.

Piccoli, G., Ives, B. (2005), "Review: IT-dependent strategic initiatives and sustained competitive advantage: a review and synthesis of the literature", MIS Quarterly, Vol. 29 No.4, pp.747-76.

Porter, M., Millar, V. (1985), "How information gives you competitive advantage", Harvard Business Review, Vol. 63 No.4, pp.149-74.

Rosenthal, R., Dimatteo, M.R. (2001), "Meta-analysis: recent developments in quantitative methods for literature reviews", Annual Review of Psychology, Vol. 52 No.1, pp.59-82.

Tallon, P.P., Kraemer, K.L. (2007), "Fact or fiction? A sensemaking perspective on the reality behind executives' perceptions of IT business value", Journal of Management Information Systems, Vol. 24 No.1, pp.13-54.

Teece, D. (2007), "Explicating dynamic capabilities: the nature and microfoundations of (sustainable) enterprise performance", Strategic Management Journal, Vol. 28 pp.1319-50.

Teece, D., Pisano, G., Shuen, A. (1997), "Dynamic capabilities and strategic management", Strategic Management Journal, Vol. 18 No.7, pp.509-33.

Urbach, N., Smolnik, S., Riempp, G. (2008), "A methodological examination of empirical research on information systems success: 2003 to 2007", Proceedings of the Fourteenth Americas Conference on Information Systems, Toronto, Canada, August 14-17, . 
Urbach, N., Smolnik, S., Riempp, G. (2009), "The state of research on information systems success - a review of existing multidimensional approaches", Business \& Information Systems Engineering, Vol. 1 No.4, pp.315-25.

Wade, M., Hulland, J. (2004), "The resource-based view and information systems research: review, extension, and suggestions for future research", MIS Quarterly, Vol. 28 No.1, pp.107-42.

Wernerfelt, B. (1984), "A resource-based view of the firm", Strategic Management Journal, Vol. 5 No.2, pp.171-80.

Wheeler, B. (2002), "NEBIC: a dynamic capabilities theory for assessing netenablement", Information Systems Research, Vol. 13 No.2, pp.125-46.

Wolf, F. (1986), Meta-analysis: Quantitative Methods for Research Synthesis, Sage, Beverly Hills, CA, .

\section{Further Reading}

King, W.R., He, J. (2006), "A meta-analysis of the technology acceptance model", Information \& Management, Vol. 2006 No.42, pp.740-55.

\section{Appendix 1. Meta-analysis articles}

Ahearne, M., Jones, E., Rapp, A. and Mathieu, J. (2008), "High touch through high tech: the impact of salesperson technology usage on sales performance via mediating mechanisms”, Management Science, Vol. 54 No. 4, pp. 671-85.

Andersen, T. and Segars, A. (2001), "The impact of IT on decision structure and firm performance: evidence from the textile and apparel industry”, Information and Management, Vol. 39 No. 2, pp. 85-100.

Anderson, M.C., Banker, R.D. and Ravindran, S. (2006), "Value implications of investments in information technology”, Management Science, Vol. 52 No. 9, pp. 1359-76.

Ayal, M. and Seidmann, A. (2009), "An empirical investigation of the value of integrating enterprise information systems: the case of medical imaging informatics", Journal of Management Information Systems, Vol. 26 No. 2, pp. 43-68.

Banker, R.D., Bardhan, I.R. and Chang, H. (2006), "Plant informations systems, manufacturing capabilities, and plant performance”,MIS Quarterly, Vol. 30 No. 2, pp. 315-37.

Bardhan, I., Whitaker, J. and Mithas, S. (2006), "Information technology, production process outsourcing, and manufacturing plant performance”, Journal of Management Information Systems, Vol. 23 No. 2, pp. 13-40. 
Barua, A., Konana, P., Whinston, A.B. and Yin, F. (2004), “An empirical investigation of netenabled business value”, MIS Quarterly, Vol. 28 No. 4, pp. 585-620.

Benaroch, M., Jeffery, M., Kauffman, R.J. and Shah, S. (2007), “Option-based risk management: a field study of sequential information technology investment decisions”, Journal of Management Information Systems, Vol. 24 No. 2, pp. 103-40.

Bernroider, E.W.N. (2008), "IT governance for enterprise resource planning supported by the Delone-Mclean model of IS success”,Information and Management, Vol. 45 No. 5, pp. 257-69.

Bertschek, I. and Kaiser, U. (2004), "Productivity effects of organizational change: microeconometric evidence”, Management Science, Vol. 50 No. 2, pp. 394-404.

Bharadwaj, S., Bharadwaj, A. and Bendoly, E. (2007), "The performance effects of complementarities between information systems, marketing, manufacturing, and supply chain processes”, Information Systems Research, Vol. 18 No. 4, pp. 437-53.

Bhatt, G.D. and Grover, V. (2005), "Types of information technology capabilities and their role in competitive advantage: an empirical study", Journal of Management Information Systems, Vol. 22 No. 2, pp. 253-77.

Bose, I., Pal, R. and Ye, A. (2008), "ERP and SCM systems integration: the case of a valve manufacturer in China”, Information and Management, Vol. 45 No. 4, pp. 233-41.

Bradley, R.V., Pridmore, J.L. and Byrd, T.A. (2006), "Information systems success in the context of different corporate cultural types: an empirical investigation”, Journal of Management Information Systems, Vol. 23 No. 2, pp. 267-94.

Byrd, T.A. and Davidson, N.W. (2003), "Examining possible antecedents of it impact on the supply chain and its effect on firm performance”, Information and Management, Vol. 41 No. 2, pp. 243-55.

Byrd, T.A. and Turner, D. (2001), "An exploratory examination of the relationship between flexible IT infrastructure and competitive advantage”, Information and Management, Vol. 39 No. 1, pp. 41-52.

Byrd, T.A. and Turner, D. (2001), "An exploratory analysis of the value of the skills of IT personnel: their relationship to IS infrastructure and competitive advantage”, Decision Sciences, Vol. 32 No. 1, pp. 21-54.

Chang, J.C.-J. and King, W.R. (2005), "Measuring the performance of information systems: a functional scorecard”, Journal of Management Information Systems, Vol. 22 No. 1, pp. 85-115. 
Chari, M.D.R., Devaraj, S. and David, P. (2008), “The impact of information technology investments and diversification strategies on firm performance”, Management Science, Vol. 54 No. 1, pp. 224-34.

Chatterjee, D., Pacini, C. and Sambamurthy, V. (2002), "The shareholder-wealth and tradingvolume effects of information-technology infrastructure investments”, Journal of Management Information Systems, Vol. 19 No. 2, pp. 7-42.

Cheng, Z. and Nault, B.R. (2007), "Industry level supplier-driven it spillovers”, Management Science, Vol. 53 No. 8, pp. 1199-216.

Davamanirajan, P., Kauffman, R.J., Kriebel, C.H. and Mukhopadhyay, T. (2006), “Systems design, process performance, and economic outcomes in international banking”, Journal of Management Information Systems, Vol. 23 No. 2, pp. 65-90.

Demirhan, D., Jacob, V.S. and Raghunathan, S. (2007), "Strategic IT investments: the impact of switching cost and declining IT cost”,Management Science, Vol. 53 No. 2, pp. 208-26.

Dewan, S. and Ren, F. (2007), "Risk and return of information technology initiatives: evidence from electronic commerce announcements", Information Systems Research, Vol. 18 No. 4, pp. 370-94.

Dewan, S., Shi, C. and Gurbaxani, V. (2007), "Research note - investigating the risk-return relationship of information technology investment: firm-level empirical analysis", Management Science, Vol. 53 No. 12, pp. 1829-42.

Dibbern, J., Winkler, J. and Heinzl, A. (2008), "Explaining variations in client extra costs between software projects offshored to India”,MIS Quarterly, Vol. 32 No. 2, pp. 333-66.

Dong, S., Xu, S.X. and Zhu, K.X. (2009), "Research note - information technology in supply chains: the value of IT-enabled resources under competition", Information Systems Research, Vol. 20 No. 1, pp. 18-32.

Duh, R.-R., Chow, C.W. and Chen, H. (2006), "Strategy, it applications for planning and control, and firm performance: the impact of impediments to IT implementation”, Information and Management, Vol. 43 No. 8, pp. 939-49.

Fink, L. and Neumann, S. (2009), "Exploring the perceived business value of the flexibility enabled by information technology infrastructure”, Information and Management, Vol. 46 No. 2, pp. 90-9.

Frohlich, M. (2002), “e-Integration in the supply chain: barriers and performance”, Decision Sciences, Vol. 33 No. 4, pp. 537-556. 
Gold, A., Malhotra, A. and Segars, A. (2001), "Knowledge management: an organizational capabilities perspective”, Journal of Management Information Systems, Vol. 18 No. 1, pp. 185214.

Grewal, R., Lilien, G.L. and Mallapragada, G. (2006), “Location, location, location: how network embeddedness affects project success in open source systems”, Management Science, Vol. 52 No. 7, pp. 1043-56.

Guimaraes, T., Cook, D. and Natajaran, N. (2002), "Exploring the importance of business clockspeed as a moderator for determinants of supplier network performance”, Decision Sciences, Vol. 33 No. 4, pp. 629-44.

Hitt, L., Wu, D.J. and Zhou, X. (2002), "Investment in enterprise resource planning: business impact and productivity measures," Journal of Management Information Systems, Vol. 19 No. 1, pp. 71-98.

Hulland, J., Wade, M.R. and Antia, K.D. (2007), “The impact of capabilities and prior investments on online channel commitment and performance", Journal of Management Information Systems, Vol. 23 No. 4, pp. 109-42.

Hussain, Z., Wallace, J. and Cornelius, N.E. (2007), “The use and impact of human resource information systems on human resource management professionals”, Information and Management, Vol. 44 No. 1, pp. 74-89.

Im, K.S., Dow, K. and Grover, V. (2001), "Research report: a reexamination of IT investment and the market value of the firm - an event study methodology", Information Systems Research, Vol. 12 No. 1, pp. 103-17.

Ismail, N.A. and King, M. (2006), "The alignment of accounting and information systems in SMES in Malaysia”, Journal of Global IT Management, Vol. 9 No. 3, pp. 24-42.

Jahangir, K., Somers, T.M. and Bhattacherjee, A. (2007), “The impact of ERP implementation on business process outcomes: a factor-based study", Journal of Management Information Systems, Vol. 24 No. 1, pp. 101-34.

Jeffers, P. (2008), "Information technology and process performance: an empirical investigation of the interaction between IT and non-IT resources”, Decision Sciences, Vol. 39 No. 4, pp. 70335.

Karimi, J., Somers, T.M. and Bhattacherjee, A. (2007), “The role of information system resources in ERP capability building and business process outcome”, Journal of Management Information Systems, Vol. 24 No. 2, pp. 221-60. 
Kearns, G.S. and Sabherwal, R. (2006), "Strategic alignment between business and information technology: a knowledge-based view of behaviors, outcome, and consequences”, Journal of Management Information Systems, Vol. 23 No. 3, pp. 129-62.

Kim, K.K., Umanath, N.S. and Kim, B.H. (2005), “An assessment of electronic information transfer in B2b supply-channel relationships”, Journal of Management Information Systems, Vol. 22 No. 3, pp. 293-320.

Kudyba, S. and Diwan, R. (2002), "Research report: increasing returns to information technology”, Information Systems Research, Vol. 13 No. 1, pp. 104-11.

Kulp, S.C., Lee, H.L. and Ofek, E. (2004), "Manufacturer benefits from information integrations with retail customers”, Management Science, Vol. 50 No. 4, pp. 431-44.

Law, C.C.H. and Ngai, E.W.T. (2007), "ERP systems adoption: an exploratory study of the organizational factors and impacts of ERP success”, Information and Management, Vol. 44 No. 4, pp. 418-32.

Lee, C.S. (2001), "Modeling the business value of information technology”, Information \& Management, Vol. 39 No. 3, pp. 191-210.

Menon, N., Yaylacicegi, U. and Cezar, A. (2009), "Differential effects of the two types of information systems: a hospital-based study”,Journal of Management Information Systems, Vol. 26 No. 1, pp. 297-316.

Mishra, A.N., Konana, P. and Barua, A. (2007), “Antecedents and consequences of internet use in procurement: an empirical investigation of US manufacturing firms”, Information Systems Research, Vol. 18 No. 1, pp. 103-20.

Mzoughi, N., Bahri, N. and Ghachem, M.S. (2008), “Impact of supply chain management and ERP on organizational performance and competitive advantage: case of Tunisian companies”, Journal of Global IT Management, Vol. 11 No. 3, pp. 24-45.

Navarette, C.J. and Pick, J.B. (2002), “Information technology expenditure and industry performance: the case of the Mexican banking industry”, Journal of Global Information Technology Management, Vol. 5 No. 2, pp. 7-28.

Neirotti, P. and Paolucci, E. (2007), “Assessing the strategic value of information technology: an analysis on the insurance sector”,Information and Management, Vol. 44 No. 6, pp. 568-82.

Oh, W. and Pinsonneault, A. (2007), “On the assessment of the strategic value of information technologies: conceptual and analytical approaches”, MIS Quarterly, Vol. 31 No. 2, pp. 239-65. 
Osei-Bryson, K.-M. and Ko, M. (2004), "Exploring the relationship between information technology investments and firm performance using regression splines analysis”, Information and Management, Vol. 42 No. 1, pp. 1-13.

Park, J., Shin, S.K. and Sanders, L.G. (2007), "Impact of international information technology transfer on national productivity”,Information Systems Research, Vol. 18 No. 1, pp. 86-102.

Rai, A., Patnayakuni, R. and Seth, N. (2006), "Firm performance impacts of digitally enabled supply chain integration capabilities”, MIS Quarterly, Vol. 30 No. 2, pp. 225-46.

Ray, G., Wu, D. and Konana, P. (2009), “Competitive environment and the relationship between IT and vertical integration”, Information Systems Research, Vol. 20 No. 4, pp. 585-603.

Saeed, K.A., Malhotra, M.K. and Grover, V. (2005), "Examining the impact of interorganizational systems on process efficiency and sourcing leverage in buyer-supplier dyads”, Decision Sciences, Vol. 36 No. 3, pp. 365-96.

Saraf, N., Langdon, C.S. and Gosain, S. (2007), "IS application capabilities and relational value in interfirm partnerships”, Information Systems Research, Vol. 18 No. 3, pp. 320-39.

Shu, W. and Strassmann, P.A. (2005), "Does information technology provide banks with profit?”, Information and Management, Vol. 42 No. 5, pp. 781-7.

Sobol, M. and Klein, G. (2009), "Relation of CIO background, IT infrastructure, and economic performance”, Information and Management, Vol. 46 No. 5, pp. 271-8.

Soh, C., Markus, L.M. and Goh, K.H. (2006), “Electronic marketplaces and price transparency: strategy, IT, and success”, MIS Quarterly, Vol. 30 No. 3, pp. 705-23.

Stoel, M.D. and Muhanna, W.A. (2009), "IT capabilities and firm performance: a contingency analysis of the role of industry and IT capability type”, Information and Management, Vol. 46 No. 3, pp. 181-9.

Subramani, M. (2004), "How do suppliers benefit from information technology use in supply chain relationships”, MIS Quarterly, Vol. 28 No. 1, pp. 45-73.

Subramani, M. and Walden, E. (2001), “The impact of e-commerce announcements on the market value of firms”, Information Systems Research, Vol. 12 No. 2, pp. 135-54.

Swierczek, F.W., Shrestha, P.K. and Bechter, C. (2005), "Information technology, productivity and profitability in Asia-Pacific banks”,Journal of Global IT Management, Vol. 8 No. 1, pp. 626.

Tallon, P.P. (2007), “A process-oriented perspective on the alignment of IT and business strategy”, Journal of Management Information Systems, Vol. 24 No. 3, pp. 227-68. 
Tallon, P.P. and Kraemer, K.L. (2007), "Fact or fiction? A sensemaking perspective on the reality behind executives' perceptions of IT business value”, Journal of Management Information Systems, Vol. 24, No. 1, pp. 13-54.

Tanriverdi, H. (2005), “Information technology relatedness, knowledge management capability, and performance of multibusiness firms”,MIS Quarterly, Vol. 29 No. 2, pp. 311-34.

Tanriverdi, H. (2006), "Performance effects of information technology synergies in multibusiness firms”, MIS Quarterly, Vol. 30 No. 1, pp. 57-77.

Thouin, M., Hoffman, J. and Ford, E. (2009), "IT outsourcing and firm-level performance: a transaction cost perspective”, Information and Management, Vol. 46 No. 8, pp. 463-9.

Wang, E.T.G., Tai, J.C.F. and Wei, H.-L. (2006), “A virtual integration theory of improved supply-chain performance”, Journal of Management Information Systems, Vol. 23 No. 2, pp. 4164.

Wu, D., Ray, G. and Whinston, A.B. (2008), "Manufacturers' distribution strategy in the presence of the electronic channel”, Journal of Management Information Systems, Vol. 25 No. 1, pp. 167-98.

Yao, Y., Dresner, M. and Palmer, J. (2009), “Private network EDI vs internet electronic markets: a direct comparison of fulfillment performance”, Management Science, Vol. 55 No. 5, pp. 84352.

Zain, M., Rose, R.C., Abdullah, I. and Masrom, M. (2005), “The relationship between information technology acceptance and organizational agility in Malaysia”, Information and Management, Vol. 42 No. 6, pp. 829-39.

Zhu, K. and Kraemer, K.L. (2005), "Post-adoption variations in usage and value of e-business by organizations: cross-country evidence from the retail industry”, Information Systems Research, Vol. 16 No. 1, pp. 61-84. 